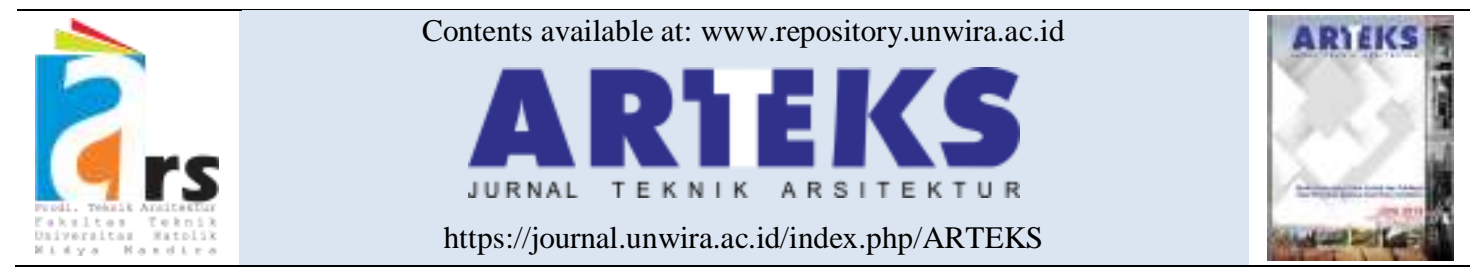

Research paper

doi: $10.30822 /$ arteks.v6i2.725

\title{
Cultural significance of the Jatiroto sugar factory official house in Stasiun Street Lumajang Regency
}

\author{
Antariksa* ${ }^{*}$, Herry Santosa ${ }^{\circledR}$, Wahyuni Eka Sari ${ }^{\mathbb{C}}$ \\ Department of Architecture, Faculty of Engineering, Universitas Brawijaya \\ Jl. MT. Haryono, no. 167, Malang, Indonesia
}

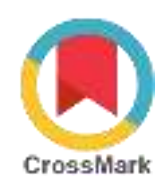

\begin{tabular}{|c|c|}
\hline ARTICLE INFO & ABSTRACT \\
\hline $\begin{array}{l}\text { Article history: } \\
\text { Received November } 01,2020 \\
\text { Received in revised form Dec. } 19,2020 \\
\text { Accepted January } 04,2021 \\
\text { Available online August } 01,2021\end{array}$ & $\begin{array}{l}\text { The assessment of cultural significance is important to the processes } \\
\text { involved in the determination of building preservation policies. The } \\
\text { cultural significance is mostly invisible or intangible in a cultural } \\
\text { heritage building and contained in the form of value or meaning } \\
\text { which are sometimes misinterpreted and this means it is possible to }\end{array}$ \\
\hline $\begin{array}{l}\text { *Corresponding author: Antariksa } \\
\text { Department of Architecture, Faculty of } \\
\text { Engineering, Universitas Brawijaya, } \\
\text { Indonesia } \\
\text { Email: antariksa@ @ub.ac.id } \\
\text { ORCID: https://orcid.org/0000-0002-5270- } \\
4750\end{array}$ & $\begin{array}{l}\text { judge a building as worthy or unworthy to be preserved for the } \\
\text { interests of the past, present, and future through the evaluation its } \\
\text { importance. Moreover, some important elements are usually } \\
\text { contained in a cultural heritage building which can be excavated } \\
\text { through their cultural significance. This research was, therefore, } \\
\text { conducted to determine the cultural significance of residential } \\
\text { buildings in the Jatiroto Sugar Factory area complex at Lumajang } \\
\text { Regency, East Java to be used in formulating policies required to } \\
\text { preserve the structures as a cultural heritage for the benefit of future } \\
\text { generations. This involved the use of the descriptive method to } \\
\text { describe the situation in the field while the weighted evaluative } \\
\text { method was applied to evaluate the cultural significance value of the } \\
\text { building and its elements. The results were used as the criteria to } \\
\text { determine the cultural significance of the official house of the } \\
\text { Jatiroto Sugar Factory which can be applied as the reference to } \\
\text { formulate the cultural significance criteria for similar cultural } \\
\text { heritage buildings in other locations. }\end{array}$ \\
\hline
\end{tabular}

\section{Introduction}

Building preservation is an activity to maintain the meaning or significance of a specific cultural heritage to ensure it is sustained and also provide some benefits and functions (Australia Icomos International Council on Monuments and Sites 1981). One of the stages involved in this preservation process is the assessment of the cultural heritage values such as the function, meaning, location, material, as well as associations and places and these are usually obtained in the form of data to be used in determining the worthiness of a building for preservation (Truscott 2014). This, therefore, makes cultural significance a hidden part of cultural heritage which requires an in-depth study to show and an important stage in the preservation or conservation process needed to be maintained or raised. This is important due to the fact that a place or building has meanings which are manifested without any misunderstanding and these include the aesthetic, historical, scientific, social, and spiritual values (Australia Icomos International Council on Monuments and Sites 1981; Ramli, Antarikssa, and Santosa 2020).

Jatiroto Sugar Factory is the center of sugar production activities in Lumajang Regency and its surroundings but the building is currently experiencing a decline in quality and this means it needs to be preserved, especially the official housing section. The residential building was 
observed to be undergoing several changes with some parts left untreated and damaged without maximum maintenance, thereby, reducing its meaning as observed in the room designed to be part of the house which is now losing its function. The official residence has a unique aesthetic and cultural value which is not only part of the sugar factory but also has the potential to serve as the visual image and source of attraction for Lumajang Regency due to its Dutch colonial nuances. Meanwhile, the assessment of the cultural significance value has the ability to produce the appropriate conservation policy to ensure the buildings receive proper maintenance and are able to survive. It is, however, important to note that the building is currently functioning as an official house which accommodates the residents' daily activities and the conservation efforts are expected to ensure it does not lose its meaning and function in supporting these activities.

The cultural significance contained in a building is very important to the assessment of its worthiness for preservation (Purwaningsih 2015; Prabawa, Adhika, and Wirawibawa 2019). The values also have the ability to function as the guidelines to assess the superiority of buildings and cultural areas (Sutomo and Surya 2018) as well as to determine building preservation policies (Bakri et al. 2015; Suryono, Sudikno, and Salura 2013). It is important to note that inherent building elements can also be used as cultural significance values (Timang, Antariksa, and Ari 2016; Paramitha, Kastawan, and Widiastuti 2017; Rahmadhiani 2016). Moreover, buildings which are well preserved and have high cultural significance have the ability to improve the environment quality (Wahyuni 2019) and also used as the reference for the assessment of the damage to cultural buildings (Sutanto 2014) through the use of cultural significance contained to interpret the place (Martokusumo 2017). The building element character has also been reported to have a significant effect in assessing the significance of a cultural heritage building (Ramli, Santosa, and Antariksa 2020), especially the visual and spatial aspects which are important factors to determine the worthiness of a building (Putra, Antariksa, and Mohammad 2017; Estin, Antariksa, and Suryasari 2017; Prameswari, Antariksa, and Suryasari 2017).

This research is, therefore, expected to provide a new theory on the values of cultural significance as a reference to determine conservation direction and the visual, architectural, and spatial values were also used as the spatial pattern of the building.

\section{Method}

This research was conducted on the official house of the Jatiroto Sugar Factory located in Kaliboto Lor Village, Jatiroto Subdistrict, Lumajang Regency as shown in figure 1. It is located on three main roads including Stasion, Jatiroto, and Ranupakis streets which connect the residence to the main factory area. Several dozens of the houses are uninhabited and unoccupied and the samples used consisted of six houses located on Stasiun Street including 4 twin, 1 single, and 1 stilt types which were used to represent the four different types of houses in the area as shown in table 1 .

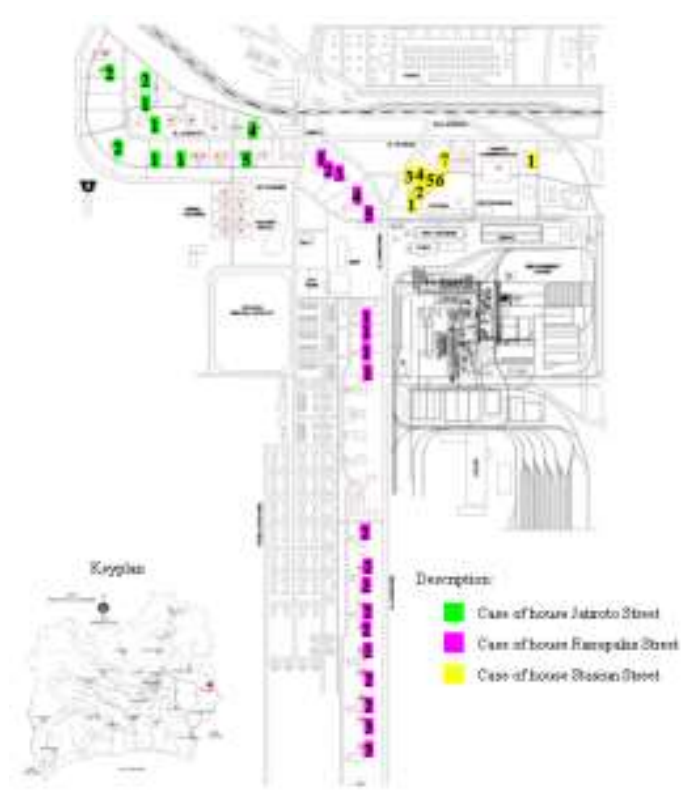

Figure 1. The layout of the Jatiroto factory house Source: (Vembrista 2017)

Table 1. Houses sample of station street

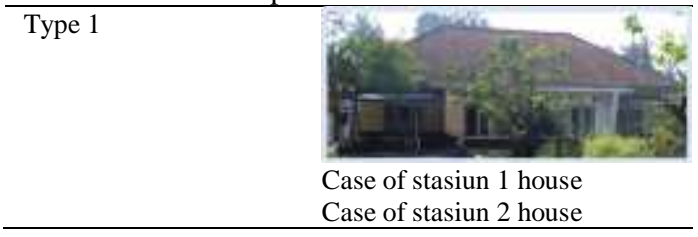




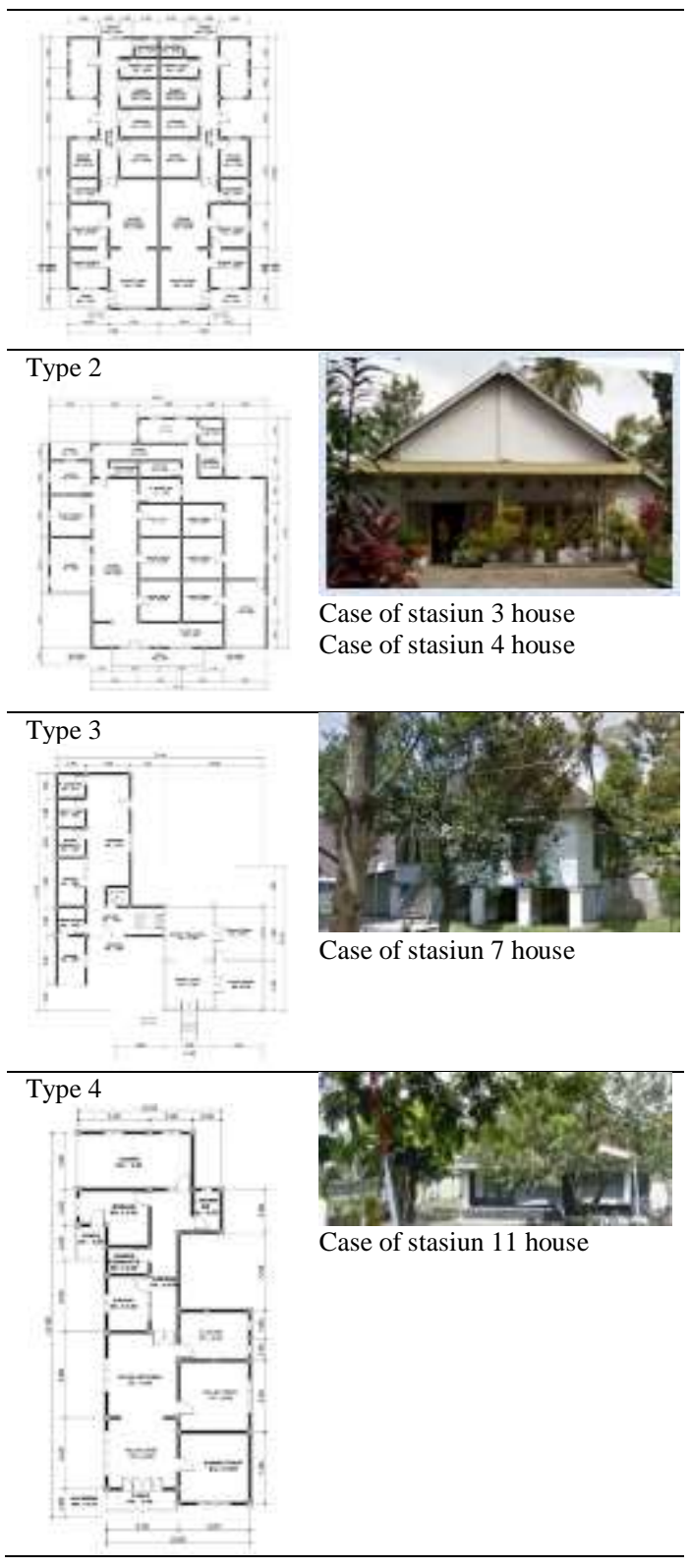

A descriptive qualitative method was used in this research and the data were collected through field observations, interviews, and pictures to describe the situation in the field while an evaluative method with scoring techniques was applied to assess the cultural significance value of the buildings and their elements.

The method of analysis was adjusted to the existing problem formulation and this means descriptive analysis technique was employed in accordance with the phenomena and issues in the object location. This involved the processing of the raw data to obtain maximum results in the form of the descriptions of the existing buildings' physical conditions after the identification of their character. Meanwhile, the evaluative method involved the determination of the building's cultural significance based on certain criteria presented in low, medium, or high levels as well as through numerical assessments. Each criterion was made to correspond with the condition of the cultural significance of the building elements and each level was provided a certain value such that 1 was used for low, 2 for medium, and 3 for high scores.

The initial stage of the research was field observations and the data obtained were in the form of the physical condition of the buildings identified through descriptive methods. The next stage was used to determine the cultural significance values by combining and elaborating theories from previous literature and studies and the results were used to evaluate the building's physical condition through the evaluative method in the form of 1, 2, and 3 scoring values. The final stage involved the determination of the conservation direction using average scoring results developed into three categories of low, medium, and high potential which were further used to obtain the preservation directions of the physical building.

\section{Result and discussion}

Cultural significance

The cultural significance was explained by Kerr (1990) as the beauty of the buildings contained in a city preserved to represent a certain period or style and this is necessary because of the features required to be protected. Some of the privileges owned include the oldest, largest, longest, or the first building, and several benchmarks mentioned to obtain the desired aesthetic value include the shape, scale, structure, material, smell, sound, and ornament. Kerr (1990) also explained that the historical value of a place is influenced by the important events or activities at the location and these values are even higher when the public memory of the event persists and the location nuance is complete.

Furthermore, Sutomo and Surya (2018) showed it is possible to measure cultural significance using cultural and historical values criteria while the use of sub-criteria such as age, social, economic, and political sub-criteria are 
different from the opinion of Kerr (1990) which include architectural elements, style, ornament, material, exterior, rarity, and the area's environment. Meanwhile, some of the criteria observed to be the same for Sutomo and Surya (2018) and Kerr (1990) include historical, physical, social, aesthetic, and scientific values.

Catanese, Ollswang, and Snyder (1979) in Sutomo and Surya (2018) defined the six criteria in building assessment to include history, rarity, features, aesthetics, plurality, and quality of influence while Kerr (1990) in Sutomo and Surya (2018) added other values such as commercial, social, and scientific values. Martokusumo (2017) further showed the need to interpret meaning in the process of preservation in order to determine and utilize the existing physical potentials and functions such as the historical, uniqueness, and character of the place which is also known as the spirit of place.

Cultural significance is usually used in analyzing the feasibility of preserving ancient buildings through variables of place, material, layout, the function of related objects, associations, meanings, and interpretations. Timang, Antariksa, and Ari (2016) also proposed other criteria to determine the conservation direction using the analysis of cultural meanings suggested by Catanese, Ollswang, and Snyder (1979) such as age, aesthetics, extraordinariness, historical role, rarity, building character, and the image of the area.

Kerr (1990) also classified aesthetic values into elements of form, scale, structure, layout in buildings, materials, smells, sounds, and ornaments with the architectural character further described as part of the aesthetic value. Moreover, Wahyuni (2019) has a different opinion on aesthetic value and this involves the inclusion of a building façade while Sutomo and Surya (2018) described it as the style, ornament, architectural elements of buildings, and the materials. Catanese, Ollswang, and Snyder (1979) also represent aesthetic value with form, style, structure, layout, and type of the building while Martokusumo (2017) included form, material, sound, smell, and taste. Paramitha, Kastawan, and Widiastuti (2017); Rahmadhiani (2016) also divided the aesthetic value from building elements into roofs, balustrades, walls, windows, doors, floors, and ceilings while Bakri et al. (2015) added shape, color, texture, material, smell, and sound. Subsequently, aesthetic values were further classified by Hastijanti (2016) into form, structure, and ornament.

The architectural value is also included in the character section and this generally focuses more on building elements such as roofs, walls, doors, windows, floors, columns, ornaments, activities in buildings, textures, and orientation. This is in line with the explanation of Suryono, Sudikno, and Salura (2013); Paramitha, Kastawan, and Widiastuti (2017); Rahmadhiani (2016); Kerr (1990); Sutomo and Surya (2018). Furthermore, Hastijanti (2016) added the authenticity of shape and building maintenance value into its architectural character and they are both used in assessing the feasibility of preserving a building. The authenticity is mostly in the quantity of space which is used in the building's spatial assessment.

Table 2. Cultural significance value according to some researchers

\begin{tabular}{cll}
\hline No. & Criteria & Sub-criteria \\
\hline 1 & Aesthetic value (Kerr 1990; Wahyuni 2019; & Shape (Kerr 1990; Catanese, Ollswang, and Snyder 1979; \\
& Sutomo and Surya 2018; Catanese, Ollswang, and & Martokusumo 2017; Bakri et al. 2015) \\
& Snyder 1979; Martokusumo 2017; Paramitha, & Scale (Kerr 1990) \\
Kastawan, and Widiastuti 2017; Rahmadhiani & Structure (Kerr 1990; Catanese, Ollswang, and Snyder 1979) \\
2016; Bakri et al. 2015; Hastijanti 2016). & Spatial layout (Kerr 1990; Catanese, Ollswang, and Snyder \\
& 1979) \\
& Material (Kerr 1990; Sutomo and Surya 2018; Martokusumo \\
& 2017; Bakri et al. 2015; Timang, Antariksa, and Ari 2016; \\
& Suryono, Sudikno, and Salura 2013) \\
& Smell (Kerr 1990; Martokusumo 2017; Bakri et al. 2015) \\
& Sound (Kerr 1990; Martokusumo 2017; Bakri et al. 2015) \\
& Ornament (Kerr 1990; Sutomo and Surya 2018; Suryono, \\
& Sudikno, and Salura 2013) \\
& Façade (Wahyuni 2019) \\
& Taste (Martokusumo 2017) \\
& Style (Sutomo and Surya 2018; Catanese, Ollswang, and Snyder \\
& 1979) \\
& Architectural elements (Sutomo and Surya 2018; Feilden 2007; \\
& Prabawa, Adhika, and Wirawibawa 2019) \\
\hline
\end{tabular}




\begin{tabular}{|c|c|c|}
\hline No. & Criteria & Sub-criteria \\
\hline & & $\begin{array}{l}\text { Roof (Paramitha, Kastawan, and Widiastuti 2017; Rahmadhiani } \\
\text { 2016; Suryono, Sudikno, and Salura 2013) } \\
\text { Balustrade (Paramitha, Kastawan, and Widiastuti 2017; } \\
\text { Rahmadhiani 2016) } \\
\text { Wall (Paramitha, Kastawan, and Widiastuti 2017; Rahmadhiani } \\
\text { 2016; Suryono, Sudikno, and Salura 2013) } \\
\text { Window (Paramitha, Kastawan, and Widiastuti 2017; } \\
\text { Rahmadhiani 2016; Suryono, Sudikno, and Salura 2013) } \\
\text { Door (Paramitha, Kastawan, and Widiastuti 2017; Rahmadhiani } \\
\text { 2016; Suryono, Sudikno, and Salura 2013) } \\
\text { Floor (Paramitha, Kastawan, and Widiastuti 2017; Suryono, } \\
\text { Sudikno, and Salura 2013) } \\
\text { Ceiling (Paramitha, Kastawan, and Widiastuti 2017; } \\
\text { Rahmadhiani 2016) } \\
\text { Column (Rahmadhiani 2016; Suryono, Sudikno, and Salura } \\
\text { 2013) } \\
\text { Color (Bakri et al. 2015) } \\
\text { Texture (Bakri et al. 2015; Suryono, Sudikno, and Salura 2013) }\end{array}$ \\
\hline 2 & $\begin{array}{l}\text { Historical value (Kerr 1990; Wahyuni 2019; } \\
\text { Sutomo and Surya 2018; Catanese, Ollswang, and } \\
\text { Snyder 1979; Martokusumo 2017; Kurniawan } \\
\text { 2013; Paramitha, Kastawan, and Widiastuti 2017; } \\
\text { Rahmadhiani 2016; Bakri et al. 2015; Suryono, } \\
\text { Sudikno, and Salura 2013; Hastijanti 2016) }\end{array}$ & Age (Sutomo and Surya 2018; Feilden 2007) \\
\hline 3 & $\begin{array}{l}\text { Architectural value (Suryono, Sudikno, and Salura } \\
\text { 2013) }\end{array}$ & $\begin{array}{l}\text { Roof (Suryono, Sudikno, and Salura 2013) } \\
\text { Wall (Suryono, Sudikno, and Salura 2013) } \\
\text { Door (Suryono, Sudikno, and Salura 2013) } \\
\text { Window (Suryono, Sudikno, and Salura 2013) } \\
\text { Floor (Suryono, Sudikno, and Salura 2013) } \\
\text { Column (Suryono, Sudikno, and Salura 2013) } \\
\text { Ornament (Suryono, Sudikno, and Salura 2013) } \\
\text { Activities in buildings (Suryono, Sudikno, and Salura 2013) } \\
\text { Texture (Suryono, Sudikno, and Salura 2013) } \\
\text { Orientation (Suryono, Sudikno, and Salura 2013) }\end{array}$ \\
\hline 5 & Maintainability (Hastijanti 2016) & $\begin{array}{l}\text { Damage level (Hastijanti 2016) } \\
\text { The percentage of remaining buildings (Hastijanti 2016) } \\
\text { Cleanliness (Hastijanti 2016) }\end{array}$ \\
\hline 6 & $\begin{array}{l}\text { Usage value (Feilden 2007; Prabawa, Adhika, and } \\
\text { Wirawibawa 2019) }\end{array}$ & $\begin{array}{l}\text { Function (Feilden 2007; Prabawa, Adhika, and Wirawibawa } \\
\text { 2019; Timang, Antariksa, and Ari 2016) }\end{array}$ \\
\hline
\end{tabular}

Maintainability, however, includes the damage level, percentage of the remaining buildings, and cleanliness. The building usage value was, however, described by Feilden (2007); Prabawa, Adhika, and Wirawibawa (2019) and used as a benchmark in determining building preservation. It also serves as a reference to understand the space function and usage of a building. Kerr (1990) further explained that the historical value of a place is influenced by the importance of events or activities held in the location, existing public memory, and the complete location nuances. The value was also described by Kerr (1990); Wahyuni (2019); Catanese, Ollswang, and Snyder (1979); Martokusumo (2017); Bakri et al. (2015) to be the development of historical stories in ancient times in relation to the formation of a region or its surroundings.
Historical events observed and discussed in the present affect the building value and some of the factors considered by Sutomo include age, social, economic, and political sub-criteria which are different from those proposed by Kerr (1990). Martokusumo (2017) also incorporated association elements while Kurniawan (2013) explained the value by dividing it into three categories including political history, economy, and socio-culture. Moreover, it was considered by Paramitha, Kastawan, and Widiastuti (2017) from existing photo documentation and articles containing historical stories from the cultural heritage. According to Bakri et al. (2015), the value is based on existing images, events, influences, activities, and association with important events and the focus of Suryono, Sudikno, and Salura (2013) was on the authenticity of the buildings in the past and 
accommodated in the present time. Furthermore, Hastijanti (2016) discussed the observation of this value in historical stories through the use of building architecture, city development, and the nation's struggle. Meanwhile, the commercial value was discovered to be based solely on economic value.

Table 2 shows several criteria of cultural significance developed by different researchers and the aesthetic value was found to be described in terms of architectural value while some values such as smell, sound, and taste are not usable as references in the physical preservation of buildings. Meanwhile, the classification further shows the possibility of formulating the cultural significance criteria as a reference in the building's physical preservation. However, table 3 presents the criteria for the architectural character as part of cultural significance as formulated by previous researchers.

Table 3. Architectural character as part of the criteria of cultural significance

\begin{tabular}{lll}
\hline No. & Criteria & Sub-criteria \\
\hline 1 & Aesthetic value & $\begin{array}{l}\text { Shape } \\
\text { Spatial layout }\end{array}$ \\
\hline 2 & Historical value & Age \\
\hline 3 & Architectural & Roof \\
& value & Wall \\
& Door \\
& Window \\
& Floor \\
& Column \\
& Ornament \\
& Activities in buildings \\
& Texture \\
\hline
\end{tabular}

\begin{tabular}{lll}
\hline No. & Criteria & Sub-criteria \\
\hline 4 & $\begin{array}{l}\text { Authenticity of } \\
\text { the shape }\end{array}$ & Orientation \\
\hline 5 & Maintainability & $\begin{array}{l}\text { Damage level } \\
\text { The percentage of remaining } \\
\text { buildings } \\
\text { Cleanliness }\end{array}$ \\
\hline 6 & Usage value & Function \\
\hline
\end{tabular}

Cultural significance at the Jatiroto Sugar factory official house

a. Aesthetic halue (table 4)

The Jatiroto Sugar Factory Official House is located on three main roads in the same area as the factory. The house generally has a rectangular plan and a triangle visible part with the plan observed to be varied between symmetrical and asymmetrical and the house is classified into three types which are single, twin, and stilt. Moreover, space is divided equally on the right and side of the twin building while the plans of the stilt and single houses are asymmetrical and the symmetry is only visible by drawing a centerline on the plan.

The layout of the house is divided into five zones or areas which are public, semipublic, private, service, and unused areas. The public areas include the terrace and living room, the semi-public area is in the living room, the private area is the bedroom, service area consists of the kitchen and bathroom while the unused areas are generally space previously functioning but now left empty and some other spaces at the back of the building.

Table 4. The cultural significance of aesthetic values

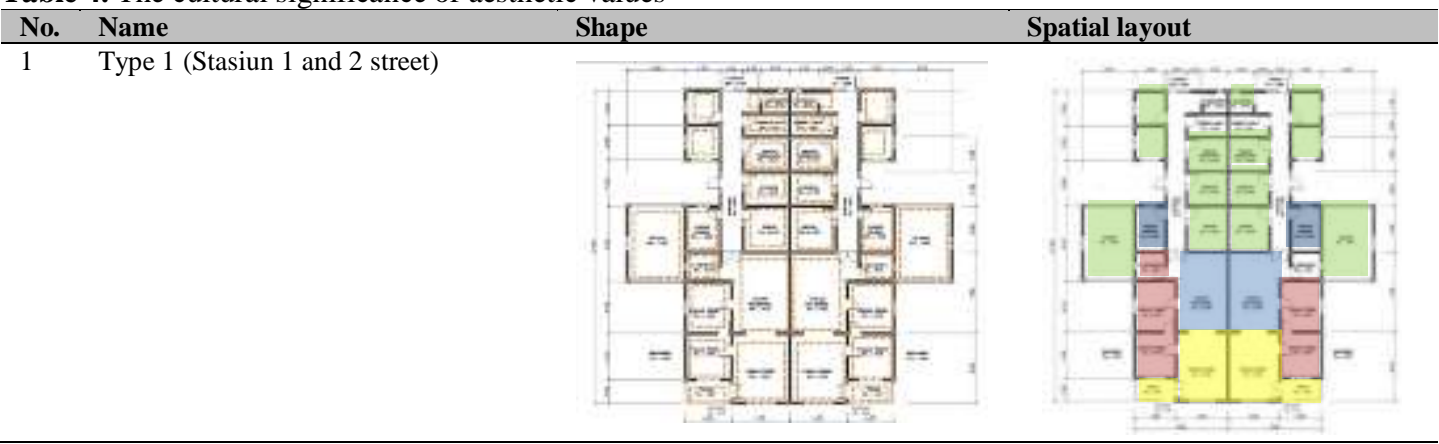




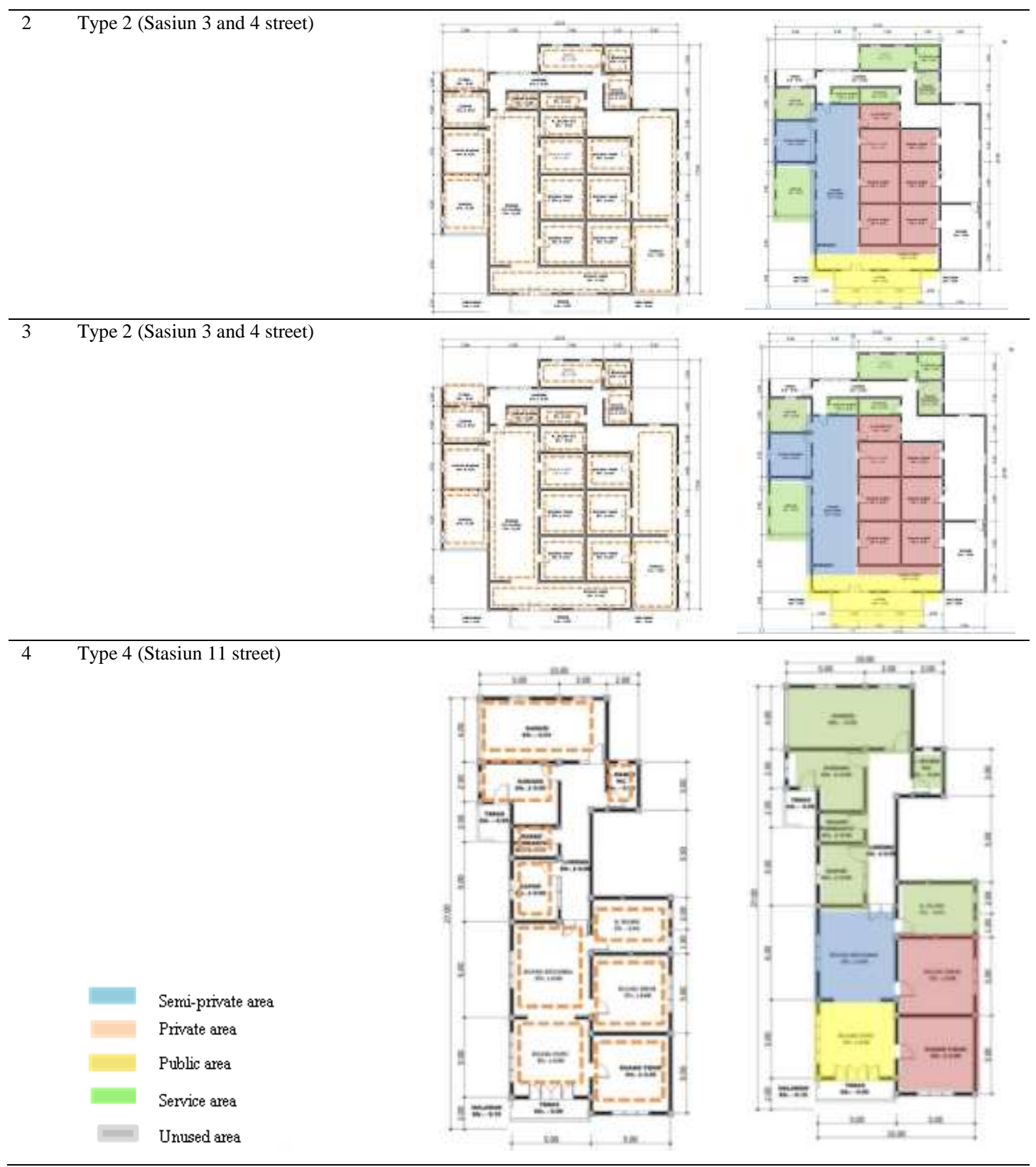

b. Historical value

The buildings are generally 92 years old because they were averagely constructed in 1928 . They have, however, experienced some changes in the interior patterns including the plan and number of rooms with the changes in the form found as a logical consequence of adding rooms or changing the space function.

c. Architectural values (table 5)

The roofs are in different forms but the shield types are most widely used in the buildings while some are combined with gable roofs, especially in the twin houses. The main material used for the roofs is earth tiles but another material, corrugated iron, is also used for cover mostly in additional building parts such as the garages while saddle roof is used at the back. Moreover, the slope of the roof is approximately $40^{\circ}$ to ease the quick flow of rainwater and a concrete cast is usually placed at the front to protect the windows from splashing rainwater.

The wall constructed using brick material serves as a separator between the spaces while a 
door is used as the link. The door and window building elements have several models designed using a combination of wood and glass and are also observed to receive the highest maintenance through the change in paint color or materials at different sizes as well as several ventilation holes included at different models. The door usually has an estimated height of $2.1 \mathrm{~m}$ and width of $1.35 \mathrm{~m}$ for the two-leaf model and a width of $0.8 \mathrm{~m}$ for the single-leaf model while the windows are approximately $2.3 \mathrm{~m}$ high and $0.67 \mathrm{~m}$ wide for each shutter. Moreover, there are other door and window combination models such as three-leaf and three shutters to four shutters as well as some door models and blind windows.

Ceramic material with a dimension of $20 \mathrm{~cm} \mathrm{x}$ $20 \mathrm{~cm}$ is used for the floor while the column at the front of the house is designed to have a shape observed to be getting wider and bigger upwards with the lower part found to be $20 \mathrm{~cm}$ wide while the upper part is $55 \mathrm{~cm}$ at a height of $3 \mathrm{~m}$. Moreover, building ornaments are placed on the front wall while the terrace has a small pebble patch or natural stone motif on its wall to provide a rough texture impression on the building.

The building on Stasiun Street is oriented towards the northwest, leads to the main road, and is observed to be facing the factory area. Furthermore, the layout of the main building is integrated into the service area which is located at the back of the building because the area is considered dirty. The building is designed to function as a residence with the space divided into a living room, family room, bedroom, kitchen, and bathroom with the indoor activities generally related to the family.

\section{d. Authenticity of the shape}

The authenticity of the architectural shape is determined by the amount of space remaining. The 92-year-old Jatiroto sugar factory official house has been experiencing several changes such that most of the spaces previously used for different activities have now been abandoned. For example, some of the rooms are not used due to the availability of several other rooms which are used by the owners when needed while the unused ones are changed to a warehouse or just left empty.

The building has an average of 12 to 30 rooms in one house with the twin house observed to be having 28 rooms in total. Some of the rooms added are due to the desire of the homeowner to have a room in the front area or the main room and not in the back while rooms are reduced only when they are severely destroyed but this rarely happens considering the fact that only some elements such as the doors, windows, and roofs experience damages while the walls are still very strong.

Table 5. The cultural significance of building elements

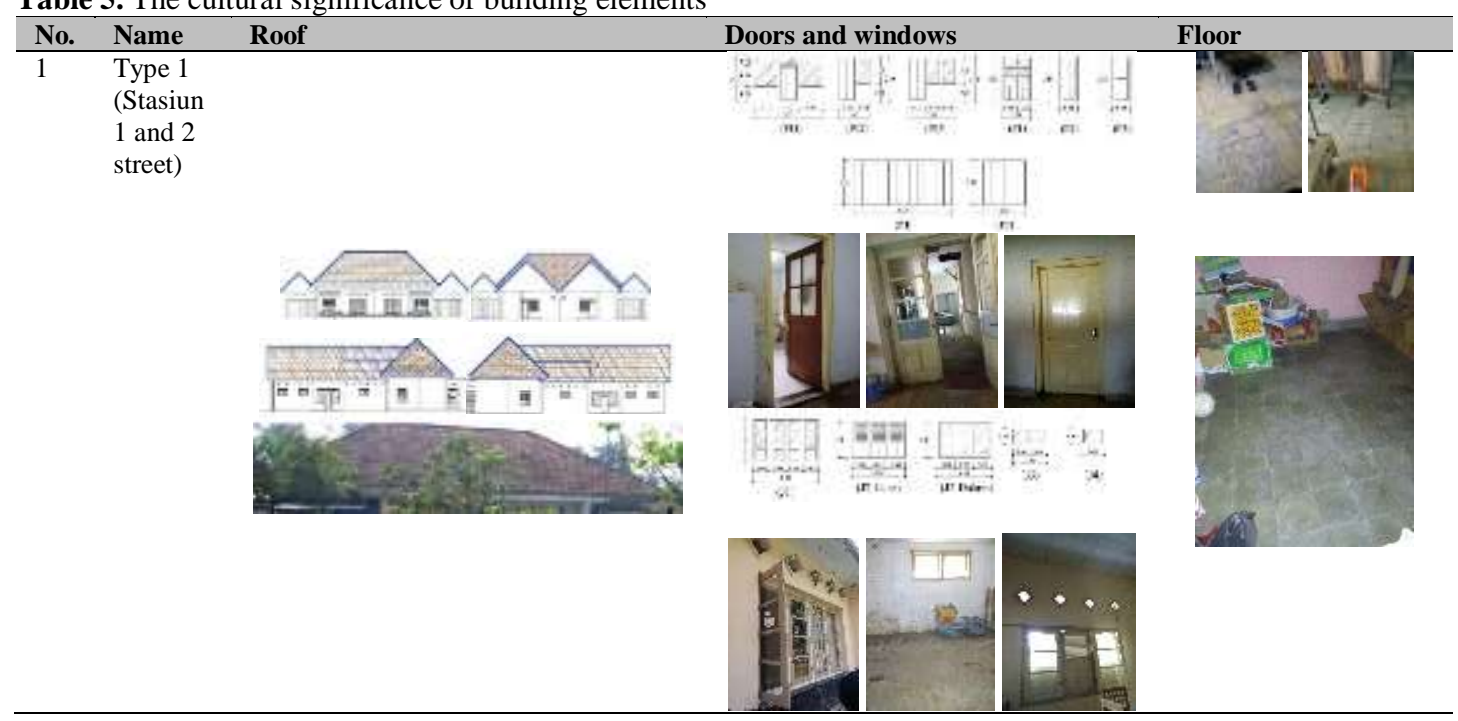



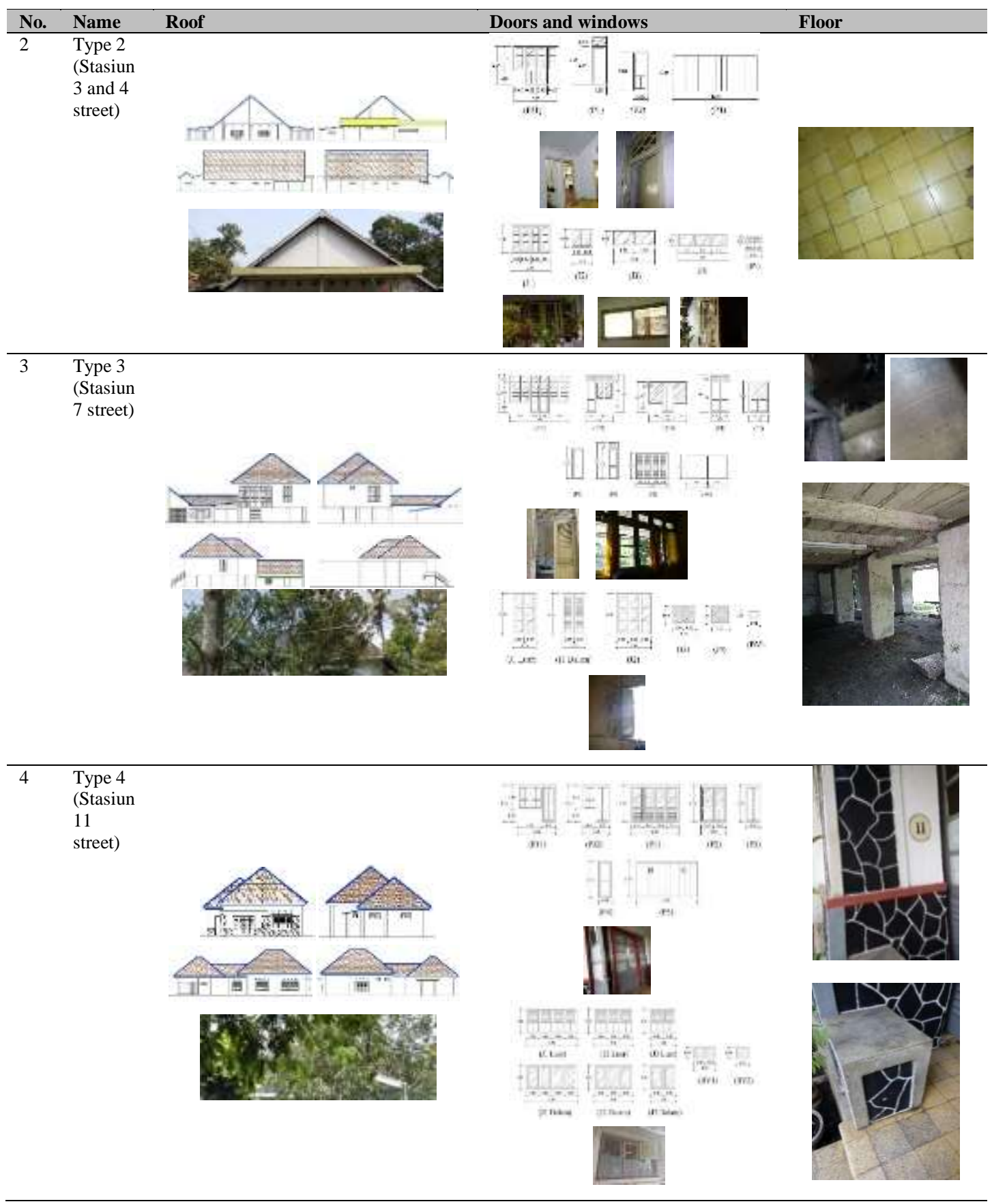

e. Maintainability (table 6)

Maintainability is also applicable in determining the cultural significance of a building based on the damage level, percentage of remaining buildings, and cleanliness which can be used to evaluate the feasibility of a building. A higher level of damage or lesser percentage of remaining buildings indicates a higher possibility for changes or improvements in a building and this means high values would be obtained in the assessment of cultural significance, thereby, leading to the need for significant physical changes. 
Table 6. Cultural significance of maintainability values

\begin{tabular}{lll}
\hline No $\quad$ Name \\
\hline 1 \\
Type 1 \\
(Stasiun 1 \\
and 2 \\
street)
\end{tabular}

The level of damage in the building studied was found to be between minor and moderate with the unmaintained part observed to be the neglected and unoccupied spaces in the back and those with a lot of damages include the roofs, moldy and chipped walls, as well as the brittle doors and windows. This is considered normal due to the fact that the building is old. Meanwhile, some changes have also been made in the room and building function as observed from the back area initially designed as a maid's room left unused or converted to a storage area because several people no longer use maids. The very large area of the house is also inefficient because it is considered to be spacious. Moreover, the percentage of the remaining buildings is approximately $90 \%$ to $95 \%$ with a little damage discovered in the roof of the empty building and some building elements while the wall remains strong even though it is fragile and mossy. The percentage reduction was also observed to be due to the significant damage to the roof. Meanwhile, the building cleanliness when viewed as a whole is up to standard considering the fact that it is occupied but the cleanliness in each house is more visible in the part used for activities while the empty back is dirty with trash and grass due to its use as a warehouse. This is majorly associated with the difficulty in conducting thorough routine maintenance on a very large yard or garden.

f. Usage value (table 7)

This is part of the architectural character used as a benchmark in determining the cultural significance of the building by evaluating whether the function has changed or remain the same. The building studied is entirely a residence which is designed and constructed to accommodate the daily activities of the residents such as rest, relaxation, and interaction with family members. A change was, however, observed in the indoor function due to the preference of the owners, for example, the room designed for the maid has been changed to a warehouse or an empty space because many people have stopped using maids. This has led to damages at the back of the building which is indicated by a dirty environment, mossy walls, and dilapidated roof. Moreover, house owners have added several new rooms to be used as bathrooms in the main building area which has a larger space to ensure easier access and efficient movement in comparison with those located in the back area. 
Table 7. The cultural significance of usage values

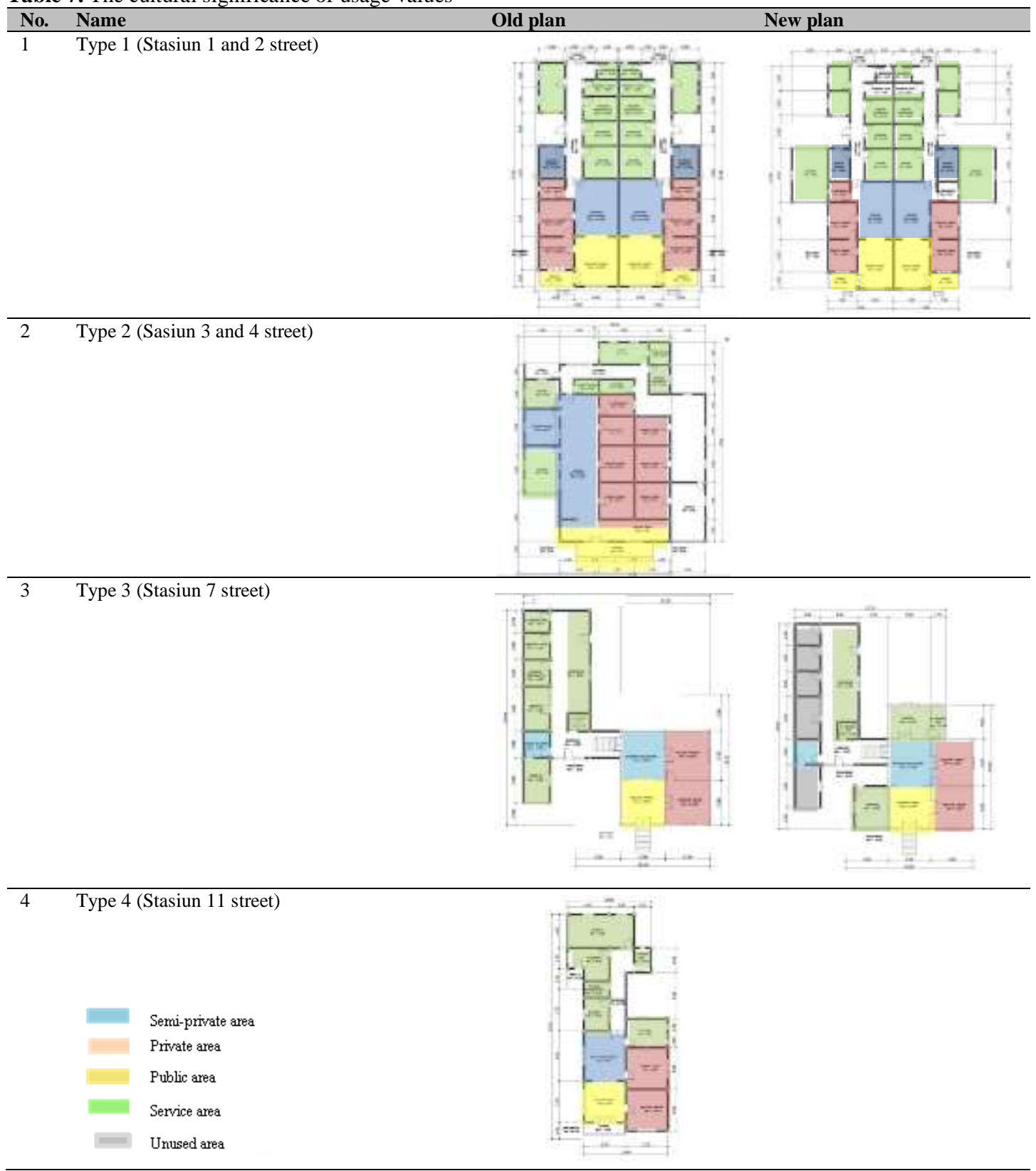

Cultural significance in conservation strategies

Cultural significance can be assessed using several criteria such as the aesthetic value $(\mathrm{E})$, historical value (S), usage value (G), architectural value (A), authenticity of the shape (B), and maintainability $(\mathrm{K})$ which were individually divided into three categories which are low, medium, and high potentials. The results showed the mean total cultural significance value for Type 1 houses in Stasiun 1 and 2 Street was 14.2 as shown in table 8, Type 2 houses in Stasiun 3 and
4 Street was 14 as indicated in table 9, Type 3 houses in Roads Station 7 Street was 15.4 as shown in table 10, and Type 4 houses in Stasiun 11 Street was 14.6 as indicated in table 11 . These values mean they all have a moderate potential to be conserved.

It is visually possible to repair the roof and walls with high value by replacing their paints with a color similar to the original while the perforated roof is to be replaced with a new ceiling material with a color that matches the 
original building. Moreover, the floors, doors, and windows are regularly maintained by cleaning and painting the moldy parts. It is also possible to repair and replace them with new materials which resemble the original ones and treating the woods by coating the varnish to increase their durability.
It is also spatially possible to maintain the existing inner space pattern by reusing empty spaces according to the original function of the building or using the empty space for new functions to make sure it is clean and not left empty.

Table 8. Assessment of cultural significance in the case of type 1 houses

\begin{tabular}{|c|c|c|c|c|c|c|c|c|c|}
\hline \multirow{2}{*}{ No. } & \multirow{2}{*}{ Variable of cultural significance criteria } & \multicolumn{6}{|c|}{ Cultural significance criteria value } & \multirow{2}{*}{ Score } & \multirow{2}{*}{ Scoring } \\
\hline & & $\mathbf{E}$ & $\mathbf{S}$ & G & $\mathbf{A}$ & $\mathbf{B}$ & $\mathbf{T}$ & & \\
\hline 1 & Shape & 2 & 2 & 3 & 3 & 3 & 2 & 15 & Moderate \\
\hline 2 & Spatial & 2 & 2 & 2 & 3 & 2 & 2 & 13 & Moderate \\
\hline 3 & Age & 3 & 3 & 2 & 3 & 2 & 2 & 15 & Moderate \\
\hline 4 & Building function & 2 & 2 & 3 & 3 & 3 & 2 & 15 & Moderate \\
\hline 5 & Space function & 2 & 2 & 3 & 3 & 3 & 2 & 15 & Moderate \\
\hline 6 & Roof & 3 & 2 & 3 & 3 & 3 & 2 & 16 & High \\
\hline 7 & Wall & 3 & 3 & 3 & 3 & 3 & 1 & 16 & High \\
\hline 8 & Door & 2 & 2 & 3 & 3 & 3 & 2 & 15 & Moderate \\
\hline 9 & Window & 2 & 2 & 3 & 3 & 3 & 2 & 15 & Moderate \\
\hline 10 & Floor & 2 & 3 & 3 & 3 & 3 & 2 & 16 & High \\
\hline 11 & Column & 2 & 2 & 2 & 2 & 2 & 2 & 12 & Moderate \\
\hline 12 & Ornaments & 2 & 2 & 2 & 2 & 2 & 2 & 12 & Moderate \\
\hline 13 & Activities in building & 3 & 2 & 3 & 3 & 3 & 2 & 16 & High \\
\hline 14 & Space orientation & 2 & 3 & 3 & 2 & 3 & 2 & 15 & Moderate \\
\hline 15 & Number of rooms & 2 & 3 & 3 & 3 & 2 & 1 & 14 & Moderate \\
\hline 16 & Damage level & 2 & 2 & 2 & 2 & 2 & 2 & 12 & Moderate \\
\hline 17 & The percentage of remaining buildings & 2 & 2 & 2 & 2 & 2 & 2 & 12 & Moderate \\
\hline \multirow[t]{3}{*}{18} & Cleanliness & 2 & 3 & 2 & 2 & 2 & 2 & 13 & Moderate \\
\hline & & \multicolumn{6}{|c|}{ TOTAL } & \multicolumn{2}{|l|}{257} \\
\hline & & \multicolumn{6}{|c|}{ Average } & 14.2 & Moderate \\
\hline
\end{tabular}

Table 9. Assessment of cultural significance in the case of type 2 houses

\begin{tabular}{|c|c|c|c|c|c|c|c|c|c|}
\hline \multirow{2}{*}{ No. } & \multirow{2}{*}{ Variable of cultural significance criteria } & \multicolumn{6}{|c|}{ Cultural significance criteria value } & \multirow{2}{*}{ Score } & \multirow{2}{*}{ Scoring } \\
\hline & & $\mathbf{E}$ & $\mathbf{S}$ & G & $\mathbf{A}$ & B & $\mathbf{T}$ & & \\
\hline 1 & Shape & 2 & 2 & 1 & 3 & 3 & 2 & 13 & Moderate \\
\hline 2 & Spatial & 3 & 2 & 2 & 3 & 2 & 2 & 14 & Moderate \\
\hline 3 & Age & 2 & 3 & 2 & 3 & 3 & 2 & 15 & Moderate \\
\hline 4 & Building function & 2 & 2 & 2 & 2 & 3 & 2 & 13 & Moderate \\
\hline 5 & Space function & 2 & 2 & 2 & 2 & 2 & 2 & 12 & Moderate \\
\hline 6 & Roof & 2 & 2 & 3 & 2 & 3 & 2 & 14 & Moderate \\
\hline 7 & Wall & 3 & 2 & 3 & 2 & 2 & 2 & 14 & Moderate \\
\hline 8 & Door & 3 & 2 & 3 & 3 & 3 & 2 & 16 & High \\
\hline 9 & Window & 3 & 2 & 3 & 3 & 3 & 2 & 16 & High \\
\hline 10 & Floor & 2 & 2 & 3 & 3 & 3 & 2 & 15 & Moderate \\
\hline 11 & Column & 2 & 2 & 2 & 3 & 2 & 2 & 13 & Moderate \\
\hline 12 & Ornaments & 2 & 3 & 3 & 3 & 3 & 2 & 16 & High \\
\hline 13 & Activities in building & 2 & 3 & 3 & 2 & 2 & 2 & 14 & Moderate \\
\hline 14 & Space orientation & 2 & 2 & 2 & 2 & 3 & 3 & 14 & Moderate \\
\hline 15 & Number of rooms & 3 & 2 & 3 & 3 & 3 & 2 & 16 & High \\
\hline 16 & Damage level & 2 & 2 & 2 & 2 & 2 & 2 & 12 & Moderate \\
\hline 17 & The percentage of remaining buildings & 2 & 2 & 2 & 2 & 3 & 2 & 13 & Moderate \\
\hline \multirow[t]{3}{*}{18} & Cleanliness & 2 & 2 & 2 & 2 & 2 & 2 & 12 & Moderate \\
\hline & & \multicolumn{6}{|c|}{ TOTAL } & 252 & \\
\hline & & & & & & & verage & 14 & Moderate \\
\hline
\end{tabular}

Table 10. Assessment of cultural significance in the case of type 3 houses

\begin{tabular}{|c|c|c|c|c|c|c|c|c|c|}
\hline \multirow{2}{*}{ No. } & \multirow{2}{*}{ Variable of cultural significance criteria } & \multicolumn{6}{|c|}{ Cultural significance criteria value } & \multirow[b]{2}{*}{ Score } & \multirow{2}{*}{ Scoring } \\
\hline & & $\mathbf{E}$ & $\mathbf{S}$ & G & $\mathbf{A}$ & B & $T$ & & \\
\hline 1 & Shape & 3 & 3 & 2 & 3 & 3 & 3 & 17 & High \\
\hline 2 & Spatial & 2 & 2 & 2 & 3 & 3 & 2 & 14 & Moderate \\
\hline 3 & Age & 3 & 3 & 2 & 3 & 2 & 2 & 15 & Moderate \\
\hline 4 & Building function & 3 & 2 & 3 & 3 & 3 & 2 & 16 & High \\
\hline
\end{tabular}




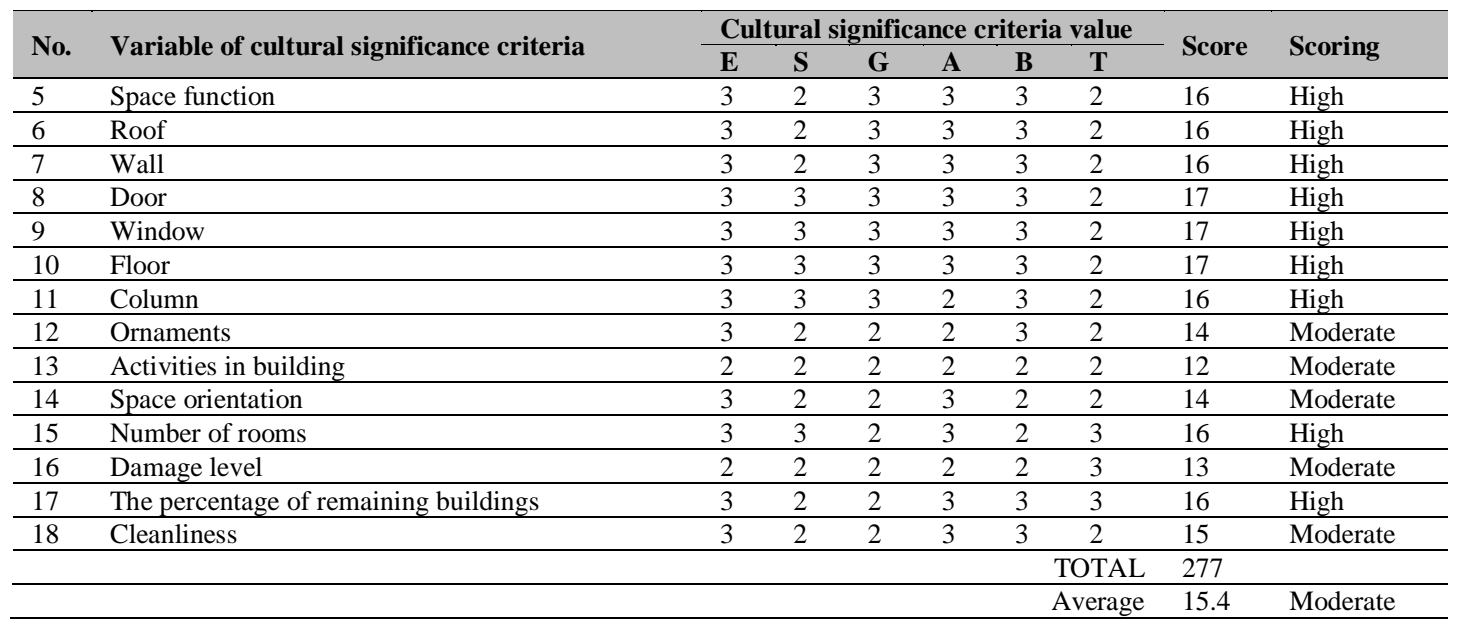

Table 11. Assessment of cultural significance in the case of type 4 houses

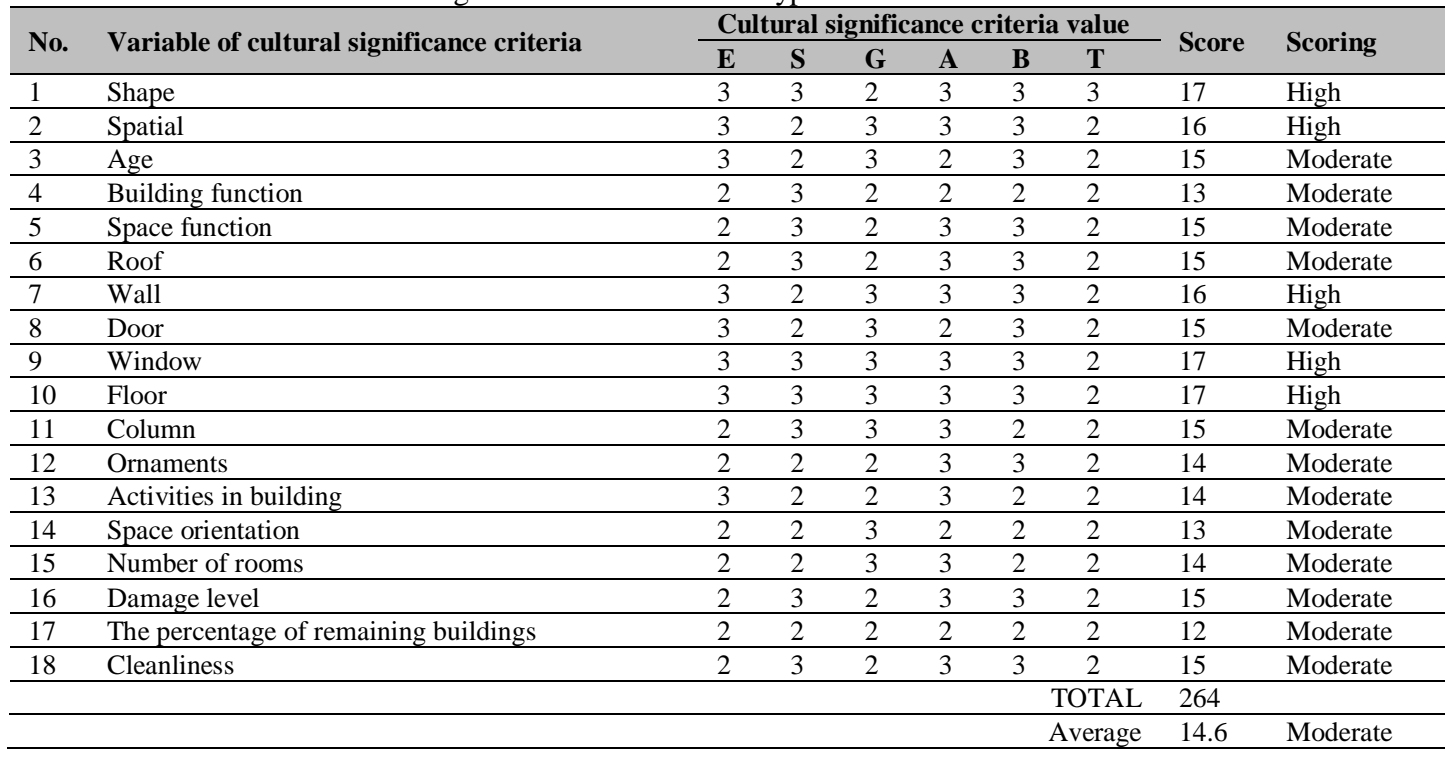

The cultural significance of the official house of the Jatiroto Sugar Factory was found to be averagely moderate and this means it is necessary to periodically maintain the good parts of the building and also to ensure the empty spaces function again.

\section{Conclusion}

This research showed an effective method to assess the feasibility of a building for preservation through the use of cultural significance value which was applied both visually and spatially. The factors used include the building's architectural character such as its aesthetic, history, usage, architecture, and maintenance.
The aesthetic value was based on the overall visible beauty of the building with the focus on its uniqueness or representation of a certain period in history. Moreover, the historical value was established on the building's age while the usage value assessed whether its function is the same as the original plan or has been changed. The architectural value evaluated the elements such as the doors, walls, windows, roofs, and floors supporting the interior functionality while the maintainability value assessed the condition, damage, and cleanliness of the building to determine the direction for its preservation.

The results showed the Jatiroto Sugar Factory official house located on Stasiun Street has a moderate potential to be preserved. This is because the entire building was built in the same 
year and function as a residence up to the present moment. It was discovered that a dominant percentage is intact and the empty spaces observed to be unmaintained are still standing firm. This building can, however, be preserved through routine maintenance and cleaning. The maintenance is expected to focus on repainting using the same color as the initial building and by coating the wood material with anti-fungal and termite-proof materials. Moreover, the damaged materials can be replaced with the same material as the original ones used in the building. It is also possible to spatially maintain the same pattern and layout as the original building by using the empty spaces according to their original function or using them for new activities to keep the spaces and building clean.

\section{References}

Australia Icomos International Council on Monuments and Sites. 1981. 'Guidelines to The Burra Charter Cultural Significance and Conservation Policy'. Australia Icomos. 1981. https://australia.icomos.org/publications/burr a-charter-practice-notes/burra-charterarchival-documents/.

Bakri, Aidatul Fadzlin, Norhati Ibrahim, Sabarinah Sh Ahmad, and Nurulhusna Qamaruz Zaman. 2015. 'Public Perception on the Cultural Significance of Heritage Buildings in Kuala Lumpur'. Procedia Social and Behavioral Sciences 202 (August): 294-302. https://doi.org/10.1016/j.sbspro.2015.08.233.

Catanese, Anthony J., Jeffrey E. Ollswang, and James C. Snyder. 1979. Introduction to Urban Planning. New York: McGraw-Hill Book Co.

Estin, Novia, Antariksa, and Noviani Suryasari. 2017. 'Pelestarian Bangunan Kolonial Belanda Di Jalan Pemuda Depok'. Jurnal Mahasiswa Jurusan Arsitektur Universitas $\begin{array}{llll}\text { Brawijaya } & 9 & \text { (2): } & 52-59\end{array}$ http://arsitektur.studentjournal.ub.ac.id/index. php/jma/article/view/334.

Feilden, Bernard. 2007. Conservation of Historic Buildings. Routledge. https://doi.org/10.4324/9780080502915.

Hastijanti, Retno. 2016. 'Analisis Penilaian Bangunan Cagar Budaya'. Research Gate. 2016.

https://www.researchgate.net/publication/308
203329_Analisis_Penilaian_Bangunan_Caga r_Budaya.

Kerr, James Semple. 1990. The Conservation Plan: A Guide to the Preparation of Conservation Plans for European Cultural Significant. Sydney: National Trust New South Wales.

Kurniawan, Nanang. 2013. 'Partisipasi Stakeholder Dalam Pelestarian Kawasan Rindam IV/ Diponegoro Kota Magelang Sebagai Kawasan Bersejarah'. JURNAL PEMBANGUNAN WILAYAH \& KOTA 9 (1): 31. https://doi.org/10.14710/pwk.v9i1.6504.

Martokusumo, Widjaja. 2017. 'Pemaknaan Tempat Dalam Pelestarian Arsitektur'. In Seminar Ikatan Peneliti Lingkungan Binaan Indonesia, 001-010. Ikatan Peneliti Lingkungan Binaan Indonesia. https://doi.org/10.32315/sem.1.001.

Paramitha, Ida Ayu Diah, I Wayan Kastawan, and Widiastuti. 2017. 'Nilai Signifikansi Cagar Budaya Hotel Inna Bali, Jalan Veteran Denpasar'. Ruang: Jurnal Lingkungan Binaan (Space: Journal of the Built Environment) 4 (2): 113-28. https://ojs.unud.ac.id/index.php/ruang/article/ view/39667/24055.

Prabawa, Made Agus Adi, I Made Adhika, and Ida Bagus Gde Wirawibawa. 2019. 'Konservasi Arsitektur Pura Berbasis Komunitas Di Pura Dasar Buana Gelgel, Klungkung'. Ruang: Jurnal Lingkungan Binaan (Space: Journal of the Built Environment) 6 (1): 5-20. https://ojs.unud.ac.id/index.php/ruang/article/ view/50073/29816.

Prameswari, Tri Ajeng, Antariksa, and Noviani Suryasari. 2017. 'Pelestarian Bangunan Kolonial Belanda Kantor Gubernur Jawa Timur (Gouverneur Kantoor Van Oost Java)'. Jurnal Mahasiswa Jurusan Arsitektur Universitas Brawijaya 5 (1): 1-9. http://arsitektur.studentjournal.ub.ac.id/index. php/jma/article/view/333.

Purwaningsih, Lucia Helly. 2015. 'Kajian Signifikansi Budaya (Cultural Significance) Pada Permukiman Pecinan Tangerang'. In "Finding The Fifth Element... After Water, Earth, Wind, and Fire" Local Wisdom and Cultural Sustainability. Yogyakarta: Universitas Atma Jaya Yogyakarta. 
https://core.ac.uk/download/pdf/144967168.p df.

Putra, Bayu Nugroho, Antariksa, and Ridjal Abraham Mohammad. 2017. 'Pelestarian Bangunan Kolonial Museum Fatahillah Di Kawasan Kota Tua Jakarta'. Jurnal Mahasiswa Jurusan Arsitektur Universitas Brawijaya 5 http://arsitektur.studentjournal.ub.ac.id/index. php/jma/article/view/338.

Rahmadhiani, Yunanistya. 2016. 'Analisis Karakter Visual Arsitektural Dan Penilaian Makna Kultural Sebagai Pendekatan Pelestarian Bangunan Kolonial Inna Bali Hotel Di Denpasar'. Ruang: Jurnal Lingkungan Binaan (Space: Journal of the Built Environment) 3 (1): 53-66. https://ojs.unud.ac.id/index.php/ruang/article/ view/20762/13569.

Ramli, Syamsun, Antariksa, and Herry Santosa. 2020. 'Assessment of Aesthetical Quality of Architectural Elements of Colonial Buildings in Jalan Basuki Rahmat, Malang'. ARTEKS : Jurnal Teknik Arsitektur 5 (1): 87-100. https://doi.org/10.30822/arteks.v5i1.250.

Ramli, Syamsun, Herry Santosa, and Antariksa. 2020. 'Signifikansi Elemen Arsitektur Bangunan Kolonial Bergaya Art Deco Di Kota Malang'. Pawon: Jurnal Arsitektur 4 (02): 63-78. https://doi.org/10.36040/pawon.v4i02.2806.

Suryono, Alwin, Antariksa Sudikno, and Purnama Salura. 2013. 'Conservation of Dutch Colonial Architecture Heritage On Rectorate Building of Education University of Indonesia in Bandung'. Journal of Basic and Applied Scientific Research 3 (8).

Sutanto, Ari. 2014. 'Faktor-Faktor Keterbengkalaian Benteng Toboali Sebagai Bangunan Bersejarah'. JURNAL PEMBANGUNAN WILAYAH \& KOTA 10 (1): 94. https://doi.org/10.14710/pwk.v10i1.7636.

Sutomo, Irham Temas, and Aidil Surya. 2018. 'Cultural Significance: Kawasan Bersejarah
Kota Siak Sri Indrapura'. In Seminar Kota Layak Huni/Livable Space: Urbanisasi Dan Pengembangan Perkotaan. Jakarta: Universitas Trisakti. https://rijurnal.lemlit.trisakti.ac.id/lslivas/arti cle/view/2763.

Timang, Vica Vanessa Sesaryo, Antariksa Antariksa, and Ismu Rini Dwi Ari. 2016. 'Pelestarian Dukun Buntula'bi Balusu Sebagai Warisan Budaya Di Kabupaten Toraja Utara'. Jurnal Penataan Ruang 11 (1): 10.

https://doi.org/10.12962/j2716179X.v11i1.52 14.

Truscott, Marilyn Claire. 2014. 'Burra Charter: The Australia ICOMOS Charter for Places of Cultural Significance (1999)'. In Encyclopedia of Global Archaeology, 107882. New York, NY: Springer New York. https://doi.org/10.1007/978-1-4419-04652_1046.

Vembrista, Gevi. 2017. 'Karakter Spasial Dan Karakter Visual Rumah Dinas Kolonial Belanda Pabrik Gula Jatiroto'. Universitas Brawijaya.

Wahyuni, Sri. 2019. 'Placemaking Sebagai Strategi Revitalisasi Kawasan. Studi Kasus: Kawasan Pecinan Kota Makassar'. Jurnal Linears $\quad 1 \quad$ (2): $103-11$. https://doi.org/10.26618/j-linears.v1i2.1815.

\section{Author(s) contribution}

Antariksa contributed to the research concepts preparation, methodologies, investigations, data analysis, visualization, articles drafting and revisions.

Herry Santosa contribute to methodology, supervision, and validation.

Wahyuni Eka Sari contribute to methodology, supervision, and validation. 
ARTEKS : Jurnal Teknik Arsitektur, Volume 6 Issue 2, August 2021

pISSN 2541-0598; eISSN 2541-1217 